\title{
Brain-derived neurotrophic factor exerts neuroprotective actions against amyloid $\beta$-induced apoptosis in neuroblastoma cells
}

\author{
JIN HEE KIM \\ Department of Neurosurgery, College of Medicine, Korea University, Seoul 136-701, Republic of Korea
}

Received February 20, 2014; Accepted August 13, 2014

DOI: $10.3892 /$ etm.2014.2033

\begin{abstract}
Alzheimer's disease (AD) brains demonstrate decreased levels of brain-derived neurotrophic factor (BDNF) and increased levels of $\beta$-amyloid peptide $(A \beta)$, which is neurotoxic. The present study assessed the impact of BDNF on the toxic effects of $A \beta_{25-35}$-induced apoptosis and the effects on BDNF-mediated signaling using the MTT assay, western blotting and reverse transcription quantitative polymerase chain reaction. $A \beta_{25-35}$ was found to induce an apoptosis, dose-dependent effect on SH-SY5Y neuroblastoma cells, which peaked at a concentration of $20 \mu \mathrm{M}$ after $24 \mathrm{~h}$. A combination of $\mathrm{A} \beta_{25-35}$ and BDNF treatment increased the levels of Akt and decreased the level of glycogen synthase kinase-3 $\beta$ (GSK3 $\beta$ ) in SH-SY5Y neuroblastoma cells. These findings indicated that BDNF administration exerted a neuroprotective effect against the toxicity of the $\mathrm{A} \beta_{25-35}$-induced apoptosis in these cells, which was accompanied by phosphoinositide 3-kinase/Akt activation and GSK $3 \beta$ phosphorylation. The mechanisms and signaling pathways underlying neuronal degeneration induced by the A $\beta$ peptide remain to be further elucidated.
\end{abstract}

\section{Introduction}

Alzheimer's disease (AD) is a neurodegenerative disorder of the human brain and is associated with loss of memory and cognitive abilities (1). AD is characterized by amyloid plaques, neurofibrillary tangles and neuronal loss (2). In AD brains, there is also an abundance of two abnormal structures: Senile plaques composed of $\beta$-amyloid peptide $(A \beta)$, that are deposited outside neuronal bodies, and neurofibrillary tangles, which are aggregates of hyperphosphorylated tau proteins that bind to microtubules within the neurons (3). Synaptic dysfunction in $\mathrm{AD}$ may be caused by accumulation of aggregated amyloid peptides (3). A $\beta$, a 40-42 amino acid peptide fragment of the

Correspondence to: Dr Jin Hee Kim, Department of Neurosurgery, College of Medicine, Korea University, 126-1 Anam-Dong, Sungbuk-Gu, Seoul 136-701, Republic of Korea

E-mail: jin014@korea.ac.kr

Key words: $\beta$-amyloid peptide, brain-derived neurotrophic factor, Akt, glycogen synthase kinase $3 \beta$, neuroblastoma cell
$\mathrm{A} \beta$ precursor, has been shown to be a key pathological feature in the formation of senile plaques (4). A $\beta$ peptides induce cell death, decrease survival rate, and increase inflammation, oxidative stress and neurotoxicity in in vitro models used to study AD $(5,6)$.

Brain-derived neurotrophic factor (BDNF) is an important neurotrophin that has been extensively studied and that may play a role in the pathology of AD. BDNF is involved in the structural and functional plasticity of the brain (7), protects neurons in the brain against insults (8) and plays a role in neural development and maintenance of the central and peripheral neurons (9). Another important intracellular regulatory protein is glycogen synthase kinase-3 $\beta$ (GSK3 $\beta$ ). This protein is phoshorylated by growth factor-stimulated signaling pathways (10). GSK3 $\beta$ is a protein kinase that also has regulatory effects on neuronal survival and plasticity. Previously, a study indicated that GSK3 $\beta$ may play a part in AD and that its deregulation may account for a number of the pathological hallmarks of $\mathrm{AD}(11)$.

In the present study, the impact of BDNF on the toxic effects of the $A \beta$-induced apoptosis was examined via the phosphoinositide 3-kinase (PI3K)/Akt signaling pathway in SH-SY5Y neuroblastoma cells.

\section{Materials and methods}

Cell culture. Human SH-SY5Y neuroblastoma cells were maintained in Dulbecco's modified Eagles's medium (DMEM) and F-12 (Gibco-BRL, Gaithersburg, MD, USA) supplemented with $10 \%$ fetal bovine serum (FBS; HyClone, Logan, UT, USA) in a humidified atmosphere of $5 \% \mathrm{CO}_{2}$ and $95 \%$ air at $37^{\circ} \mathrm{C}$. The media was replaced every two days. Prior to the experiments, the SH-SY5Y cells were plated in 96-well plates at a density of $\sim 1.5 \times 10^{4}$ cells per well (for MTT) and in six-well plates at $8 \times 10^{6}$ cells per well (all other assays). For the experiments, the cells were incubated with agents for $24 \mathrm{~h}$ at $37^{\circ} \mathrm{C}$. For a single experiment, each treatment was performed in triplicate.

Reagents. $\mathrm{A} \beta_{25-35}$ and scrambled peptides were purchased from Bachem (Weil am Rhein, Germany). BDNF and LY294002 were purchased from Sigma-Aldrich (St Louis, MO, USA). Antibodies against phosphorylated-(p-)Akt (product no. 9271), Akt (product no. 9272), p-GSK3 $\beta$ (product no. 9336) and GSK3 $\beta$ (product no. 9315) were from Cell Signaling 
Technology, Inc. (Danvers, MA, USA). The antibody against BNDF (product no. 546) was from Santa Cruz Biotechnology, Inc. (Santa Cruz, CA, USA) and the antibody against Actin (product no. 3280) was from Abcam (Cambridge, MA, USA).

Cell proliferation and MTT assay. A cell survival analysis was performed according to the MTT (Cell Titer 96 Aqueous Cell Proliferation Assay kit; Promega, Madison, WI, USA) assay method. Briefly, the cells were cultured with $\mathrm{A} \beta(0-20 \mu \mathrm{M})$ or BDNF (0-30 ng/ml), and $10 \mu \mathrm{l}$ of $4 \mathrm{mg} / \mathrm{ml}$ MTT solution was added to each well of the 96-well plate. The cells were subsequently incubated for $4 \mathrm{~h}$ in the dark. The absorbance was measured in a microplate reader at $490 \mathrm{~nm}$, and the results were expressed as a percentage of the control.

Evaluation of apoptotic cells by Annexin-V-FITC. Apoptosis was induced by incubating cells with culture medium containing $\mathrm{A} \beta(20 \mu \mathrm{M}), \mathrm{BDNF}(10 \mathrm{ng} / \mathrm{ml})$ and LY294002 $(20 \mu \mathrm{M})$. The cells were stained with Annexin-V-FITC according to the manufacturer's instructions (Molecular Probes, Eugene, OR, USA). Approximately $1 \times 10^{5}$ cells were harvested and washed with phosphate-buffered saline. The cells were resuspended in $100 \mu \mathrm{l}$ of Annexin-V binding buffer (10 mM 4-(2-hydroxyethyl)-1-piperazineethanesulphonic acid, $140 \mathrm{mM} \mathrm{NaCl}$ and $2.5 \mathrm{mM} \mathrm{CaCl} 2 ; \mathrm{pH} \mathrm{7.4)}$, incubated with $5 \mu \mathrm{l}$ of Annexin-V-FITC for $15 \mathrm{~min}$ at room temperature and counterstained with propidium iodide (final concentration, $1 \mu \mathrm{g} / \mathrm{ml}$ ). Following the incubation period, the cells were diluted with $190 \mu$ l of Annexin-V binding buffer. The cells were analyzed by flow cytometry using a Becton-Dickinson FACScan flow cytometer with Cell Quest software (Becton-Dickinson, Mountain View, CA, USA).

Western blotting. The cells were washed in fresh phosphatebuffered saline, homogenized in lysis buffer and centrifuged. Protein concentration was determined by the Bradford assay. The purified proteins were separated by polyacrylamide gel electrophoresis (SDS-PAGE) and the resolved proteins were transferred to a nitrocellulose membrane. Each membrane was incubated overnight with a 1:1000 dilution of the primary antibody at $4^{\circ} \mathrm{C}$. The membranes were treated with a $1: 1000$ dilution of peroxidase-conjugated secondary anti-rabbit or anti-mouse antibodies for $2 \mathrm{~h}$. The proteins were detected using the enhanced chemiluminescence western blotting method (GE Healthcare, Piscataway, NJ, USA). Densitometric quantification of the bands was performed using ImageJ software version 1.29x (National Institutes of Health, Bethesda, MD, USA) (12).

Reverse transcription quantitative polymerase chain reaction (RT-qPCR) analysis. Total RNA was extracted from the cells following the Promega Total RNA Isolation System manual. RT-qPCR was performed on an ABI Prism 7500 Sequence Detection System (Applied Biosystems, Inc., Foster City, CA, USA), following the manufacturer's instructions, with SYBR Green (Toyobo Corp., Osaka, Japan) used as a double-stranded DNA specific fluorescent dye. The specific primers were as follows: GSK3 $\beta$ forward, 5'-ATCCTTATCCCTCCTCA CGC-3'; and reverse, 5'-GTTATTGGTCTGTCCACGGTCT-3'; Akt forward, 5'-AGGCATCCCTTCCTTACAGC-3'; and

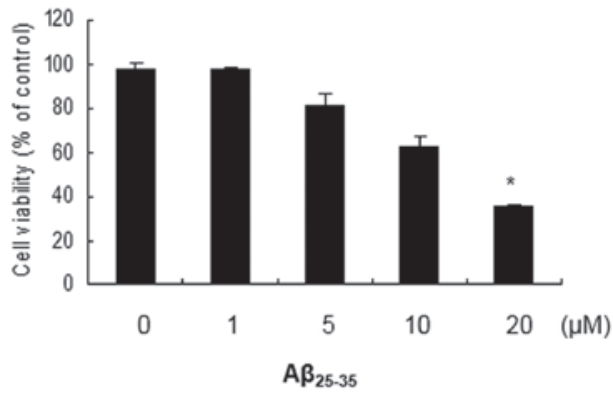

Figure 1. Dose-dependent neurotoxicity of $A \beta_{25-35}$ peptides in human SH-SY5Y neuroblastoma cells. Increasing concentrations of $A \beta_{25-35}$ were added to the culture medium of cells, and the toxicity was estimated after $24 \mathrm{~h}$ using the MTT assay. Values represent the mean \pm standard error of the mean for three different cultures, with $n=3$ dishes/culture for each concentration. ${ }^{*} \mathrm{P}<0.05$ compared with the non-treated groups. $\mathrm{A} \beta, \beta$-amyloid.

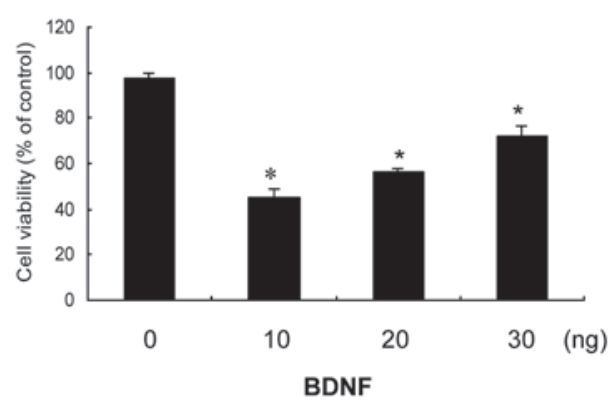

Figure 2. Neuroprotective effect of BDNF on SH-SY5Y neuroblastoma cells exposed to $\mathrm{A} \beta_{25-35}(20 \mu \mathrm{M})$. $\mathrm{A} \beta_{25-35}(20 \mu \mathrm{M})$ was added to cells in the presence of increasing concentrations of BDNF in the culture medium for $24 \mathrm{~h}$, after which toxicity was estimated using the MTT assay. Values represent the mean \pm standard error of the mean for three different cultures, with $n=3$ dishes/culture for each concentration. ${ }^{*} \mathrm{P}<0.05$ compared with groups without BDNF treatment. A $\beta, \beta$-amyloid; BDNF, brain-derived neurotrophic factor.

reverse, 5'-CAGCCCGAAGTCCGTTATCT-3'; and $\beta$-actin forward, F-5'-CGTTGACATCCGTAAAGACCTC-3'; and reverse, 5'-TAGGAGCCAGGGCAGTAATCT-3'.

Statistical analysis. Data were obtained from three separate cultures and expressed as the mean \pm standard error of the mean. Statistical comparison was determined by an analysis of variance test with the Student's t-test as the post hoc test. $\mathrm{P}<0.05$ was considered to indicate a statistically significant difference.

\section{Results}

Effect of increasing concentrations of $A \beta_{25-35}$ on cell viability. The MTT assay was used to determine $A \beta_{25-35}$-induced toxicity (Fig. 1). A $24 \mathrm{~h}$ exposure to $A \beta_{25-35}$ induced a toxic, dose-dependent effect on SH-SY5Y cells, with a maximal effect of $\sim 40 \%$ noted at a concentration of $20 \mu \mathrm{M}$. Thus, $20 \mu \mathrm{M}$ was used as the concentration for $A \beta_{25-35}$ in all further experiments. The scrambled peptide did not affect cell survival in comparison with the vehicle-treated control group: $100 \pm 3 \%$ at $20 \mu \mathrm{M}$ in the $\mathrm{A} \beta_{25-35}$ group versus $98 \pm 2 \%$ in the control group.

Effect of increasing BDNF concentrations on $A \beta_{25-35}$-treated cells. The ability of BDNF to protect SH-SY5Y cells against 

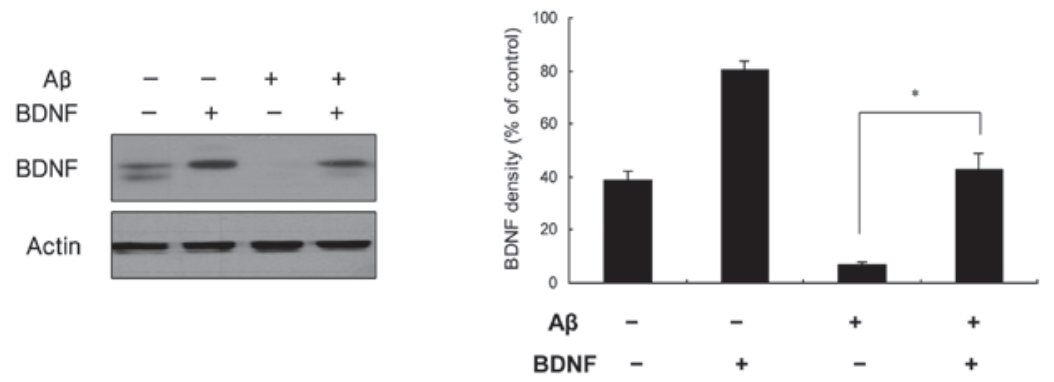

Figure 3. Neuroprotective effect of BDNF on SH-SY5Y neuroblastoma cells exposed to $\mathrm{A} \beta_{25-35}(20 \mu \mathrm{M})$. $\mathrm{A} \beta_{25-35}(20 \mu \mathrm{M})$ was added to cells in the presence of BDNF (10 ng/ml) in medium for $24 \mathrm{~h}$, after which toxicity was estimated by western blotting. Results showed that BDNF levels increased when cells were treated with $\mathrm{A} \beta_{25-35}(20 \mu \mathrm{M})$ combined with $\mathrm{BDNF}(10 \mathrm{ng} / \mathrm{ml})$. $\mathrm{A} \beta$, $\beta$-amyloid; BDNF, brain-derived neurotrophic factor.

A

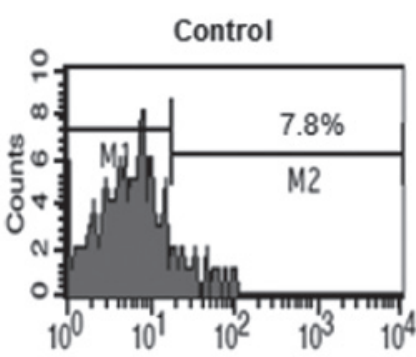

C

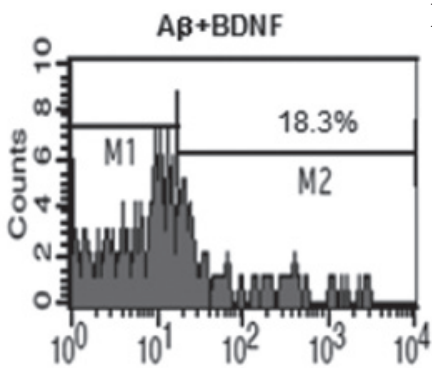

B

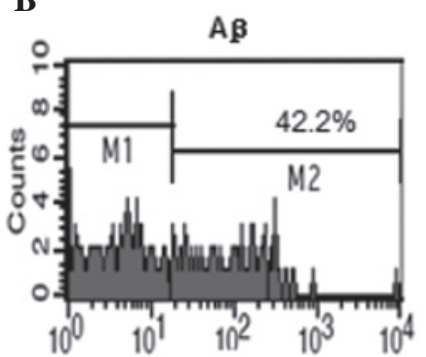

D

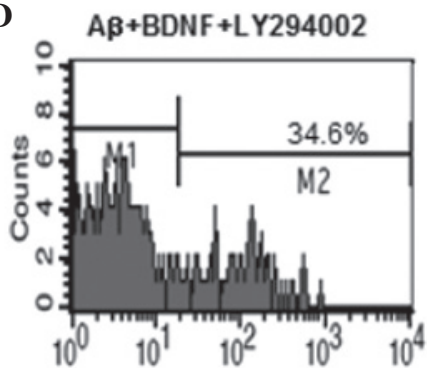

Annexin V-FITC

Figure 4. BDNF attenuates $A \beta_{25-35}$-induced apoptosis and inhibition of SH-SY5Y neuroblastoma cells. (A) Flow cytometry assay was performed to visualize the extent of programmed cell death in the control group. (B) Apoptosis of cells that were administered $\mathrm{A} \beta_{25-35}(20 \mu \mathrm{M})$. (C) Apoptosis of cells that were administered $\mathrm{A} \beta_{25-35}(20 \mu \mathrm{M})$ combined with BDNF $(10 \mathrm{ng} / \mathrm{ml})$. (D) Apoptosis of cells that were administered $\mathrm{A} \beta_{25-35}(20 \mu \mathrm{M})$ combined with BDNF $(10 \mathrm{ng} / \mathrm{ml})$ and LY294002 $(20 \mu \mathrm{M})$. M2 represents the population of cells with high annexin V binding. A $\beta$, $\beta$-amyloid; BDNF, brain-derived neurotrophic factor.

$\mathrm{A} \beta_{25-35}$-induced toxicity using the MTT assay was examined (Fig. 2). BDNF was able to protect SH-SY5Y cells from $20 \mu \mathrm{M}$ $\mathrm{A} \beta_{25-35}$-induced toxicity. This protective effect of BDNF was dose-dependent, and the effect was significant $\geq 10 \mathrm{ng} / \mathrm{ml}$. In Fig. 3, the results from a western blot analysis are shown, indicating that BDNF levels increased following exposure of the cells to treatment with a combination of $20 \mu \mathrm{M} \mathrm{A} \beta_{25-35}$ and $10 \mathrm{ng} / \mathrm{ml} \mathrm{BDNF}$.

BDNF reduces the apoptosis in SH-SY5Y cells. To examine whether $\beta_{25-35}$-induced cell death is apoptotic-like, the flow cytometry assay was performed (Fig. 4). In the control, apoptotic cells comprised $7.8 \%$ of the total number of cells. Following exposure to $20 \mu \mathrm{M} \mathrm{A} \beta_{25-35}$ for $24 \mathrm{~h}$, the number of apoptotic cells increased to $42.2 \%$. This increase was prevented by addition of BDNF $(10 \mathrm{ng} / \mathrm{ml})$. To further investigate, LY294002 $(20 \mu \mathrm{M})$, the inhibitor of Akt, was used. The apoptosis of cells increased to $34.6 \%$ following the use of LY294002 $(20 \mu \mathrm{M})$.
BDNF-mediated signal transduction in SH-SY5Y cells. Akt is a known pro-survival kinase that is activated by phosphorylation via PI3K (13). The BDNF-mediated phosphorylation of Akt was measured, as shown in Fig. 5. The treatment of cells with a combination of $\mathrm{A} \beta_{25-35}(20 \mu \mathrm{M})$ and $\mathrm{BDNF}(10 \mathrm{ng} / \mathrm{ml})$ induced a significant increase in the level of p-Akt compared to that in the cells treated only with $\mathrm{A} \beta_{25-35}(20 \mu \mathrm{M})$. This was supported by the measurement of the Akt mRNA levels, as shown in Fig. 6A.

GSK3 $\beta$ modulation of BDNF-mediated signaling. GSK $3 \beta$ is known to be inhibited by serine phosphorylation mediated by Akt, which in turn is induced by growth factor signaling (11). Treatment of cells with a combination of $\mathrm{A} \beta_{25-35}(20 \mu \mathrm{M})$ and BDNF $(10 \mathrm{ng} / \mathrm{ml})$ induced a significant decrease in the level of p-GSK3 $\beta$, compared with cells treated only with $20 \mu \mathrm{M} \mathrm{A} \beta_{25-35}$ (Fig. 7). The mRNA levels obtained for GSK3 $\beta$ supported this finding (Fig. 6B). These data indicate that GSK3 $\beta$ contributed to the neuroprotective effect of BDNF against the neurotoxicity of $\mathrm{A} \beta_{25-35}$. 

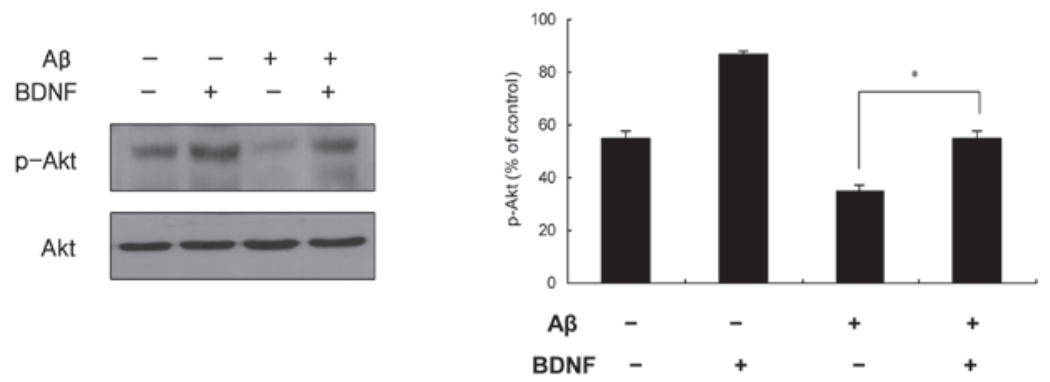

Figure 5. BDNF-mediated activation of Akt in SH-SY5Y neuroblastoma cells. Representative western blots showing protein levels of phosphorylated- and total Akt in SH-SY5Y cells. The western blots presented are representative of three independent experiments with similar results. "P $<0.05$ vs. the group treated only with $\mathrm{A} \beta_{25-35}(20 \mu \mathrm{M})$. $\mathrm{A} \beta, \beta$-amyloid; BDNF, brain-derived neurotrophic factor.

A

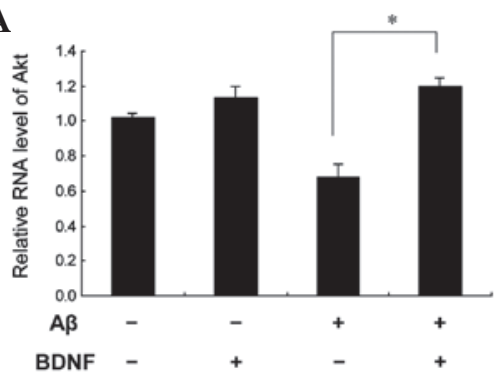

B

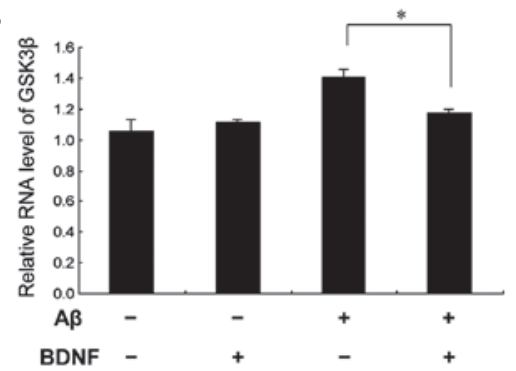

Figure 6. Levels of mRNA expression of (A) Akt and (B) GSK3 $\beta$. mRNA expression was measured by reverse transcription quantitative polymerase chain reaction. Results are shown as the mean \pm standard error of the mean of three independent experiments. ${ }^{*}<0.05$ vs. the group treated only with $\mathrm{A} \beta{ }_{25-35}(20 \mu \mathrm{M})$. $\mathrm{A} \beta, \beta$-amyloid; BDNF, brain-derived neurotrophic factor; GSK3 $\beta$, glycogen synthase kinase-3 $\beta$.
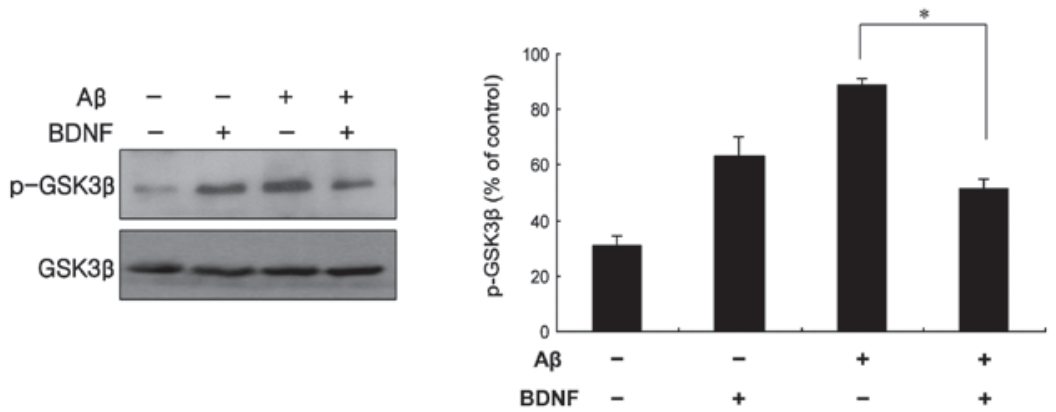

Figure 7. BDNF-mediated activation of GSK3 $\beta$ in SH-SY5Y neuroblastoma cells. Representative western blots showing the protein levels of phosphorylated (p-GSK3 $\beta$ ) and total GKS3 $\beta$ in SH-SY5Y cells. The western blots presented represent three independent experiments with similar results. "P $<0.05$ vs. the

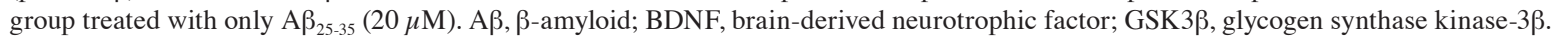

\section{Discussion}

A $\beta$ is a $40-42$ amino acid peptide fragment derived by proteolysis from the integral membrane protein known as $A \beta$ precursor protein (14). A $\beta$, the central constituent of senile plaques in $\mathrm{AD}$, is known to exert toxic effects on neurons (15). $\mathrm{A} \beta_{25-35}$ is the shorter toxic fragment corresponding to amino acids 25-35, which encompasses the $\beta$ sheet of the full protein (16). Therefore, $A \beta_{25-35}$ has been used to assess toxicity in the $\mathrm{AD}$ in vitro models (10). However, the mechanisms by which the $A \beta$ peptide exerts its neurotoxic effect are not yet understood.

BDNF levels have been observed to decrease in the parietal cortex and hippocampus of patients with $\mathrm{AD}$ (17). BDNF serum concentrations have been reported to correlate with the severity of dementia (18). Furthermore, in AD brains, neurons containing neurofibrillary tangles do not contain BDNF-immunoreactive material, whereas neurons that stain intensely for BDNF are devoid of tangles (19).

In the present study, the protective effect of BDNF against toxicity induced by $\mathrm{A} \beta_{25-35}$ in SH-SY5Y cells was assessed. The results indicated that exposure of SH-SY5Y cells to $\mathrm{A} \beta_{25-35}$ caused a decrease in viability and the cell apoptosis rate increased, while the expression of p-Akt decreased and p-GSK $3 \beta$ increased. In addition, p-Akt and p-GSK $3 \beta$ may be associated with the $\mathrm{A} \beta_{25-35}$-induced cell apoptosis.

The PI3K/Akt pathway is important for cell survival. PI3K enhances neuroprotection by regulating the level of phosphorylation and activation of Akt. Akt activity can be modulated by phosphorylation of either Thr308 or Ser473 (20). Phosphorylation of Thr308 has been reported to be stimulated by dopamine receptor activation, while 
phosphorylation of Ser473 is regulated by the activation of the N-methyl-D-aspartate receptor (21-23). Therefore, phosphorylation and activation of Akt may underlie the observed protective effect of BDNF.

GSK3 $\beta$ is a substrate of Akt, which phosphorylates and inhibits GSK3 $\beta$. Furthermore, GSK3 $\beta$ is subject to inhibitory regulation by growth factors that activate the PI3K/Akt pathway (24). Beaulieu et al (25) reported that activation of the PI3K/Akt pathway can increase the phosphorylation of GSK3 $\beta$, thereby inhibiting the activity of the latter; thus, Akt may be a regulator of GSK $3 \beta$. The present study indicated that the neuroprotective effect of BDNF against $A \beta_{25-35}$ toxicity was mediated by the inhibitory effect of Akt on GSK3 $\beta$. In conclusion, the data showed that administration of BDNF exerts neuroprotective actions against the toxic effect of the $\mathrm{A} \beta_{25-35}$-induced apoptosis in SH-SY5Y cells, which involved PI3K/Akt activation and GSK3 $\beta$ phosphorylation. The mechanism and signaling pathways underlying neuronal degeneration induced by the $A \beta$ peptide remain to be further elucidated.

\section{Acknowledgements}

This work was funded by a grant to Jin Hee Kim in 2013 from Korea University.

\section{References}

1. Mesulam MM: Neuroplasticity failure in Alzheimer's disease: bridging the gap between plaques and tangles. Neuron 24: 521-529, 1999 .

2. Dickson DW: Neuropathology of Alzheimer's disease and other dementias. Clin Geriatr Med 17: 209-228, 2001.

3. Song B, Davis K, Liu XS, Lee HG, Smith M and Liu X: Inhibition of Polo-like kinase 1 reduces beta-amyloid-induced neuronal cell death in Alzheimer's disease. Aging (Albany NY) 3: 846-851, 2011.

4. Selkoe DJ: Alzheimer's disease is a synaptic failure. Science 298: 789-791, 2002.

5. Yankner BA: Mechanisms of neuronal degeneration in Alzheimer's disease. Neuron 16: 921-932, 1996.

6. Götz J and Ittner LM: Animal models of Alzheimer's disease and frontotemporal dementia. Nat Rev Neurosci 9: 532-544, 2008.

7. Poo MM: Neurotrophins as synaptic modulators. Nat Rev Neurosci 2: 24-32, 2001.

8. Lindvall O, Kokaia Z, Bengzon J, Elmér E and Kokaia M: Neurotrophins and brain insults. Trends Neurosci 17: 490-496, 1994.

9. Lewin GR and Barde YA: Physiology of the neurotrophins. Annu Rev Neurosci 19: 289-317, 1996.

10. Cross DA, Alessi DR, Cohen P, Andjelkovich M and Hemmings BA: Inhibition of glycogen synthase kinase- 3 by insulin mediated by protein kinase B. Nature 378: 785-789, 1995.
11. Sun L, Guo C, Liu D, Zhao Y, Zhang Y, Song Z, Han H, Chen D and Zhao Y: Protective effects of bone morphogenetic protein 7 against amyloid-beta induced neurotoxicity in PC12 cells. Neuroscience 184: 151-163, 2011.

12. Abràmoff MD, Magalhães PJ and Ram SJ: Image processing with ImageJ. Biophotonics International 11: 36-42, 2004.

13. Zhao R, Zhang Z, Song Y, Wang D, Qi J and Wen S: Implication of phosphatidylinositol-3 kinase/Akt/glycogen synthase kinase-3 $\beta$ pathway in ginsenoside Rbl's attenuation of beta-amyloid-induced neurotoxicity and tau phosphorylation. J Ethnopharmacol 133: 1109-1116, 2011.

14. Amtul Z, Uhrig M and Beyreuther K: Additive effects of fatty acid mixtures on the levels and ratio of amyloid $\beta 40 / 42$ peptides differ from the effects of individual fatty acids. J Neurosci Res 89: 1795-1801, 2011.

15. Hongpaisan J, Sun MK and Alkon DL: PKC $\varepsilon$ activation prevents synaptic loss, $A \beta$ elevation, and cognitive deficits in Alzheimer's disease transgenic mice. J Neurosci 31: 630-643, 2011.

16. Kaminsky YG, Marlatt MW, Smith MA and Kosenko EA: Subcellular and metabolic examination of amyloid-beta peptides in Alzheimer disease pathogenesis: evidence for Abeta(25-35). Exp Neurol 221: 26-37, 2010.

17. Peng S, Wuu J, Mufson EJ and Fahnestock M: Precursor form of brain-derived neurotrophic factor and mature brain-derived neurotrophic factor are decreased in the pre-clinical stages of Alzheimer's disease. J Neurochem 93: 1412-1421, 2005.

18. Laske C, Stransky E, Leyhe T, Eschweiler GW, Maetzler W, Wittorf A, Soekadar S, Richartz E, Koehler N, Bartels M, Buchkremer G and Schott K: BDNF serum and CSF concentrations in Alzheimer's disease, normal pressure hydrocephalus and healthy controls. J Psychiatr Res 41: 387-394, 2007.

19. Murer MG, Boissiere F, Yan Q, Hunot S, Villares J, Faucheux B Agid Y, Hirsch E and Raisman-Vozari R: An immunohistochemical study of the distribution of brain-derived neurotrophic factor in the adult human brain, with particular reference to Alzheimer's disease. Neuroscience 88: 1015-1032, 1999.

20. Koide H, Asai T, Furuya K, Tsuzuku T, Kato H, Dewa T, Nango M, Maeda N and Oku N: Inhibition of Akt (ser473) phosphorylation and rapamycin-resistant cell growth by knockdown of mammalian target of rapamycin with small interfering RNA in vascular endothelial growth factor receptor-1-targeting vector. Biol Pharm Bull 34: 602-608, 2011.

21. Mannoury la Cour C, Salles MJ, Pasteau V and Millan MJ: Signaling pathways leading to phosphorylation of Akt and GSK-3 $\beta$ by activation of cloned human and rat cerebral $\mathrm{D}_{2}$ and $\mathrm{D}_{3}$ receptors. Mol Pharmacol 79: 91-105, 2011.

22. Sánchez-Blázquez P, Rodríguez-Muñoz $\mathrm{M}$ and Garzón J: $\mathrm{Mu}$-opioid receptors transiently activate the Akt-nNOS pathway to produce sustained potentiation of PKC-mediated NMDAR-CaMKII signaling. PLoS One 5: e11278, 2010.

23. Soriano FX, Papadia S, Hofmann F, Hardingham NR, Bading H and Hardingham GE: Preconditioning doses of NMDA promote neuroprotection by enhancing neuronal excitability. J Neurosci 26: 4509-4518, 2006.

24. Grimes CA and Jope RS: The multifaceted roles of glycogen synthase kinase 3beta in cellular signaling. Prog Neurobiol 65: 391-426, 2001.

25. Beaulieu JM, Gainetdinov RR and Caron MG: Akt/GSK3 signaling in the action of psychotropic drugs. Annu Rev Pharmacol Toxicol 49: 327-347, 2009. 